\title{
DEVELOPING IMPLEMENTATION INDICATORS FOR PUBLIC POLICY, CASE STUDY: TEHRAN AND QOM AGRICULTURAL ORGANIZATIONS
}

Mohammad Ali Haghighi Faculty member of Shahid Beheshti University, Iran E-mail: m-haghighi@sbu.ac.ir

Gholam Ali Tabarsa Faculty member of Shahid Beheshti University, Iran E-mail: G_Tabarsa@sbu.ac.ir

Hamid Reza Ghasemi Tarbiat Modarres University, Iran E-mail: S_Talaie@sbu.ac.ir

Rouhollah Bagheri Shahid Beheshti (National) University, Iran

E-mail:R.bagheri@aut.ac.ir

Shahab Talaie Shokri (Corresponding Author) Hekmat Institute for Policy and Strategic Studies, Iran E-mail: S_Talaie@sbu.ac.ir

\section{ABSTRACT}

Submission: 01/10/2015

Revision: 02/10/2015

Accept: 14/10/2015

Public policies are problem-oriented and solve a public problem. The mere act of making decisions and policies will not solve problems; rather policies must also be executed effectively. As executing policies is a crucial step in policy making, formulating indicators for policy implementation is an absolute necessity. In this article, we conducted a content analysis of elites' opinions to improve implementation of public policies. Therefore, three major factors were identified including factors involved in policy making, environment of policy implementation, and organizational structure. Sample data were taken from agricultural organizations of Tehran and Qom. For data gathering purposes, library research, interviews and questionnaires were used. To analyze the data, k-s, Pearson's correlation coefficient, confirmatory factors analysis and means comparisons were applied 
using SPSS and LISREL. Results show that all of proposed indicators and measures are valid for implementation of public policies. Regarding the importance of indicators between the two participant groups, indicators in Tehran groups proved to be more important.

Key words: policy, policy making, policy implementation, agricultural sector

\section{INTRODUCTION}

Policy making sciences have two basic aspects which are closely related to politics in their own way. The first aspect related to political sciences is power study. The second aspect related to public management includes management techniques and decision making techniques (MILANI, 2011, 46).

After codification, ratification and signification of policies, in order to execute policies, a number of actions are to be taken. A large number of rules, regulations, programs and plans should be prepared, ratified and signified to be executed by managing lines of systems and policies. Idealistic policies will raise organizations' hope for the future if adherence to principle is taken into their consideration in all cases by program codification managers.

If policies are to be left on paper and not implemented, a fruitful future cannot be assured. The administration and execution of policies should be carried out in a coordinated and correlative manner. The indexes required to implement policies seem to have received little attention. Generally, there are no codified indexes to depict the execution of policies and each organization applies indexes in accordance to their own goal.

Concerning the individuality of criteria for selecting indexes, i.e. trustworthiness, appropriateness, validity, availability, and sensitivity, it is necessary to apply indexes as a unified language in presenting comparative and operational reports and, consequently, in execution, assessment, decision making, and mission and activity management.

One of the fields in which the aforesaid point is strongly felt is agriculture. The main reason why agriculture came to mankind's notice has been to fulfill their requirements. The most ancient civilization appeared where agricultural activities were possible geographically and ecologically. As a matter of fact, other economic 
DOI: 10.14807/ijmp.v7i1.372

fields have appeared gradually according to agricultural requirements (TEHRAN CHAIN, 2007).

Also, in Imam Khomeini and the Supreme Leader's viewpoint, agriculture is of utmost importance to the country's economy. As for the codification of general policies of the government, he says: "Concern for rebuilding industrial centers should not impede attaining agricultural self-sufficiency, rather, the priority of this matter should be preserved and officials are required to take responsibility for its execution more than before. Certainly, self-sufficiency in agriculture is the gateway to freedom and to self-sufficiency in other domains" (IMAM KHOMEINI; JAMARAN, 1988).

Also, the starring role of agriculture can be easily traced in the Supreme Leader's economic thinking. In order to draw public and official attention to agriculture, he has made such statements as: "pure life and new civilization are in close connection with the availability of resources and the prosperity of agriculture (THE SUPREME LEADER, 2004), agriculture should be of concern to senior administration officials and people (THE SUPREME LEADER, 2001) investment in agriculture is an important solution for job creation" (THE SUPREME LEADER, 2009).

Concerning the aforementioned importance attached to agriculture, it seems that public policies of this field are afflicted with poor execution. Thus, the present essay aims to take steps forward through codification of indexes of policy execution based on agricultural literature and the views of Qom and Tehran Agricultural Organization experts.

\section{THEORIES}

Since the appearance of the science of public policy, political studies have been limited to normative and moral fields of governments and political institutions. By studying the works of great Western philosophers, scholars developed and explored topics such as the nature of society, government's role, government and citizen rights and liabilities (GHOLIPURE; AHANGAR, 2010, 4).

Public policies are the free distribution of public interests. The topics of public policy are the consequences of public events related to public interests (LIANG ZHIMING, 2011, 2478). Taras believes that public policy studies problems of 
DOI: 10.14807/ijmp.v7i1.372

common or particular features which, however, cause public worries and are irritating (TARAS, 2007, 568).

Effective reinforcement of public policies requires governments' rational justice and practical planning (LIANG ZHIMING, 2011, 2478). From Islam's viewpoint, public policy is a type of guidance of a political society based on Islamic principles and values and is carried out by qualified persons to further the society's interests (AMID ZANJANI, 1995, 10).

Generally, the process of public policy making can be presented through six phases: 1. identifying public problems, 2. finding alternative solutions (policies), 3. predicting consequences, 4 . selecting a favorable policy, 5. legitimating policy, and 6. execution \& evaluation of policy (ALVANI, 2001, 40).

\subsection{Execution as the gravity center of policies}

In a standard dictionary, the term "execution" is defined as accomplishing a work based on a particular plan or method (GHOLIPURE, 2008, 193). In table 1, a number of theories concerning execution are presented.

Table 1: Execution theoreticians and the presented theories

\begin{tabular}{|l|l|l|}
\hline Theoretician & Year & Theory interpretation \\
\hline $\begin{array}{l}\text { Pressman \& } \\
\text { Wildavsky }\end{array}$ & 1973 & $\begin{array}{l}\text { Execution is a part of the process of policy making. It is an } \\
\text { interactive process between what policy maker wants and } \\
\text { the procedures to accomplish it. }\end{array}$ \\
\hline Bardash & 1981 & $\begin{array}{l}\text { Based on the metaphor, play field, different kinds of } \\
\text { bargaining and negotiation. }\end{array}$ \\
\hline Porter & 1980 & $\begin{array}{l}\text { Executive structure as an analysis unit } \\
\text { and effective execution conditions. }\end{array}$ \\
\hline Mezmanian \& Sabtyre & 1980 & $\begin{array}{l}\text { Execution as an institutional concept and the } \\
\text { representation of a four-layer model, the organizational } \\
\text { models of social plans execution, the introduction of two } \\
\text { approaches, top- down and bottom-up execution analysis. }\end{array}$ \\
\hline Clista \& Elmor & 1986 & $\begin{array}{l}\text { The presentation of two approaches, top down and bottom } \\
\text { up, a synthetic approach to effective execution analysis. }\end{array}$ \\
\hline Habtyre & 2001 & $\begin{array}{l}\text { A well-thought-out and orderly collection of some sort of } \\
\text { activities }\end{array}$ \\
\hline Krut \& Wayshow & 2003 & Making policies subject to practice. \\
\hline Khalid & 2008 & $\begin{array}{l}\text { The process of changing direction of goals related to a } \\
\text { policy }\end{array}$ \\
\hline Zehming & 2011 & Careful, serious, determined practice \\
\hline Chu hyu lee & 2011 & \begin{tabular}{l} 
Public interests or the majority interests. \\
\hline
\end{tabular} \\
\hline
\end{tabular}

Before the term "execution" was coined the importance of the execution of public policy was ignored. Ultimately, Pressman and Wildavsky conducted a research to fill the gap of execution in their study of public policy. However, as James Slack 
DOI: 10.14807/ijmp.v7i1.372

says, research on the execution of public policy did not evolve very much from the mid 1980s to the first decade of twenty first century (SLACK, 2005,3).

Different definitions of execution have been presented by different researchers. Krutwaysho, in his definition of public policy execution, quoted Lester \& Sterwart saying that: Simply, execution is making policies subject to practice (HAFIZ KHALID, 2005, 88).

In another definition, the execution of public policies is defined as a careful, serious, determined practice which is in coordination with the decision making group (LIANG ZHIMING, 2011, 2476).

Also, in recent years, change in governments' structure and the formation of democratic governments culminated in enhancing public interests in the social relationship between the government, the private sector, and the society (CHUI-HUA LIU, 2011, 414).

The most complicated problem of execution is that, having made the decision for activity execution, it should be done in a way that there would be a rational similarity with what is decided on and that it would operate well in its framework (ALVANI; SHARIFZADE, 2009, 107).

Regarding policy execution, different models and approaches have been presented that we are going to mention in brief. Lester and Sterwart identified two approaches for execution: control and ordering approach and economic motives or market approach (KRUTWAYSHO, 2003).

Also, in the most recognized analytical framework of policy execution analysis, executive approaches are classified as top-down approaches such as Mazmanian and Sabatier (1983), and bottom-up approaches such as Elmor's research, and synthetic approaches such as Majun and Wildavsky's research.

In another classification of policy execution approaches, we can name classic and neoclassic approaches (PEYKANI, 2009, 50). Samuel R. Staley believes that effective factors of successful execution of policies are as follow: clarifying the measurement tools of policies, codifying standards and identical indexes, avoiding forcing the use of technology or specific approaches for policy execution, employing encouraging approaches instead of imperative approaches, terminating ineffective 
DOI: 10.14807/ijmp.v7i1.372

policies, concern for citizens' interests and preferences, involving local governments more than before (STALEY, 2006, 246). Also, Babrow claims that social and cultural factors, achieving cooperative relationships and active connections between people and groups are significant in the policy process (BABROW, 2006, 573, 579).

Therefore, in order to determine the definitions of execution, initially, a definition of the index is required to determine the indexes of execution. Lexically, index is defined as high, ridged, elevated, diagram, representative, origin, base, road guide, something or someone among other people or things, outstanding. Other definitions of the index are as follow:

- Index is a tool of representing the quality of execution or the extent of goal realization

- Indexes determine the favorability level and expected points of a specific topic.

- Indexes are quantitative and qualitative features employed in assessing inputs, processes, staff, and consequences.

- Indexes are tools of assessing the extent of goal achievement and the accuracy of move in the specified direction (NEJAT; YAVARI, 2009, 130).

This research, due to its explanatory nature, is an applied research and researchers, apart from identifying the indexes of public policy execution, are trying to classify them. Since this research deals with the present situation, it is a descriptive research and since it studies individuals' preferences through questionnaires, it is a survey.

To identify the indexes of policy execution, content analysis method is used and experts' views are applied which are presented in the form of a questionnaire. To analyze data, Kolmogroph-Smirnoph test is used to determine the normality of each variable and then Speerman's correlative test is done on variables.

Furthermore, for the purpose of the examination and assessment of the effective index in the execution of the public policies of Tehran and Qom Agricultural Organization, confirmatory factor analysis, from among factors identified from the literature and the theories, is applied to determine the meaningfulness and effectiveness of each index. 
INDEPENDENT JOURNAL OF MANAGEMENT \& PRODUCTION (IJM\&P)

http://www.ijmp.jor.br

v. 7, n. 1, January - March 2016

ISSN: 2236-269X

DOI: 10.14807/ijmp.v7i1.372

The statistical population of this research includes the experts and managers of Tehran and Qome Agricultural Organization along with university professors of policy making. Sampling was used because of the broadness and the large number of individuals. Since the sampling framework was not clarified, snowball sampling method was used in the research (COOPER, 2003). Finally, the theoretical framework is presented in table 2.

Table 2: theoretical framework

\begin{tabular}{|c|c|c|c|}
\hline Meanings & Factors & Variables & Indexes \\
\hline \multirow{22}{*}{ 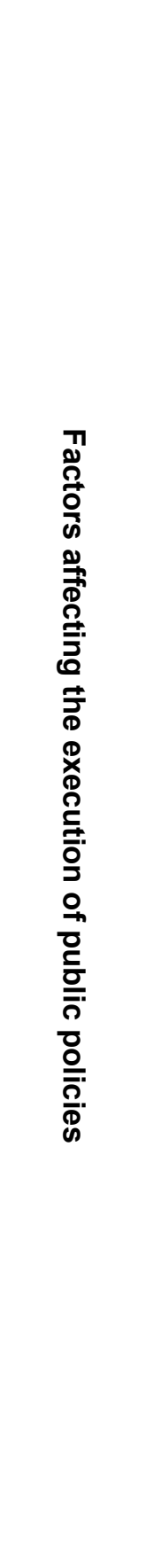 } & \multirow{11}{*}{ 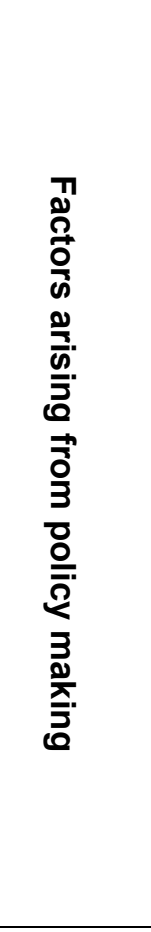 } & \multirow{2}{*}{$\begin{array}{l}\text { Standards \& } \\
\text { Goals }\end{array}$} & Clear \& real goal-setting (STEELMAN,1996) \\
\hline & & & Distinct standards \\
\hline & & \multirow{3}{*}{$\begin{array}{l}\text { The Accuracy of } \\
\text { policy theories }\end{array}$} & Rationality in policy codification (SAGHAFI,1999) \\
\hline & & & Effectiveness of policies \\
\hline & & & The relevance of policies to goals \\
\hline & & \multirow{4}{*}{ 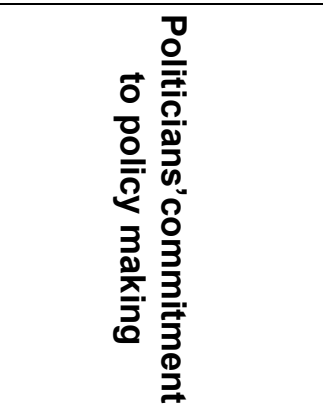 } & $\begin{array}{l}\text { Information flow monitoring by politicians (STEELMAN, } \\
\text { 1996) }\end{array}$ \\
\hline & & & $\begin{array}{l}\text { Execution of play regulations by politicians (STEELMAN, } \\
1996 \text { ) }\end{array}$ \\
\hline & & & $\begin{array}{c}\text { Application of appropriate techniques \& strategies } \\
\text { (STEELMAN, 1996) }\end{array}$ \\
\hline & & & $\begin{array}{l}\text { A small gap between ratification and execution (PALMBO; } \\
\text { CALISTA, 1990) }\end{array}$ \\
\hline & & \multirow{2}{*}{$\begin{array}{c}\text { Collective } \\
\text { consensus \& } \\
\text { agreement on the } \\
\text { execution of } \\
\text { determined policy }\end{array}$} & Dynamisms (YANOW,1990) \\
\hline & & & Dynamisms (YANOW, 1990) \\
\hline & \multirow{4}{*}{  } & \multirow{3}{*}{$\begin{array}{c}\text { Predictable } \\
\text { and unpredictable } \\
\text { events }\end{array}$} & $\begin{array}{l}\text { Defeating crisis and uncertain conditions } \\
\text { (STEELMAN,1996) }\end{array}$ \\
\hline & & & Work place safety \& health \\
\hline & & & Natural, organizational, social crisis \\
\hline & & \multirow{3}{*}{ Time \& Resources } & $\begin{array}{c}\text { Financial resources \& Facilities (STEELMAN, 1996; } \\
\text { ALVANY; GHASEMY, 1998) }\end{array}$ \\
\hline & \multirow{7}{*}{ 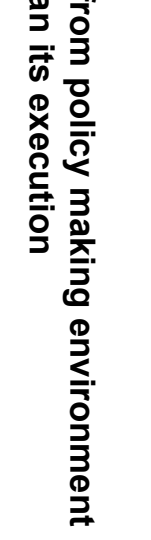 } & & Finance \& manpower (MIRSALIM, 2001) \\
\hline & & & Executive facilities (MIRSALIM, 2001) \\
\hline & & \multirow{2}{*}{ Public support } & $\begin{array}{l}\text { The effectiveness of public thoughts (GHAFURY; KAMALI, } \\
\qquad 2010 \text { ) }\end{array}$ \\
\hline & & & National will (public communion) (MIRSALIM,1380) \\
\hline & & \multirow{3}{*}{$\begin{array}{l}\text { Compatibility of } \\
\text { policies with } \\
\text { social norms \& } \\
\text { values }\end{array}$} & Principles \& beliefs \\
\hline & & & $\begin{array}{c}\text { Correspondence between work requirements, values and } \\
\text { behaviors }\end{array}$ \\
\hline & & & Correspondence with social customs \\
\hline
\end{tabular}


INDEPENDENT JOURNAL OF MANAGEMENT \& PRODUCTION (IJM\&P)

http://www.ijmp.jor.br

v. 7, n. 1, January - March 2016

ISSN: 2236-269X

DOI: 10.14807/ijmp.v7i1.372

\begin{tabular}{|c|c|c|}
\hline & \multirow{3}{*}{$\begin{array}{l}\text { Proper } \\
\text { Technology }\end{array}$} & Proper informative technology (PORTZ, 2005) \\
\hline & & Computer \& Electronic government \\
\hline & & Fax \& Email \\
\hline \multirow{15}{*}{ 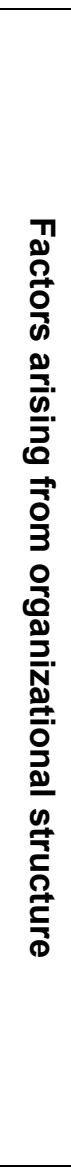 } & \multirow{6}{*}{ Executives } & $\begin{array}{l}\text { Efficient Executives (administrators) (ALVANI; GHASEMI, } \\
\text { 1998) }\end{array}$ \\
\hline & & $\begin{array}{c}\text { Individual experts with executive knowledge (HAFEZ } \\
\text { KHALID, 2008; YANO, 1990) }\end{array}$ \\
\hline & & Relative freedom in executive principles \\
\hline & & The motive of executive principles (ACHUFIELD, 2004) \\
\hline & & $\begin{array}{l}\text { Administrators' tendencies \& preferences (STEELMAN, } \\
1996 \text { ) }\end{array}$ \\
\hline & & The structures of project teams (YANO, 1990) \\
\hline & \multirow{3}{*}{$\begin{array}{c}\text { distinctive } \\
\text { liabilities \& } \\
\text { responsibilities of } \\
\text { the private sector }\end{array}$} & Distinct responsibilities (PORTZ, 2005) \\
\hline & & Responsibilities based on rules \& regulations \\
\hline & & Distinctive job description \& conditions of job taking \\
\hline & \multirow{3}{*}{ Communications } & $\begin{array}{l}\text { Inter-organizational \& executive operation communications } \\
\text { (STEELMAN, 1996) }\end{array}$ \\
\hline & & Network management (PORTZ, 2005) \\
\hline & & The use of the media (PORTZ, 2005) \\
\hline & $\begin{array}{c}\text { Operation } \\
\text { assessment } \\
\text { system }\end{array}$ & $\begin{array}{l}\text { Appropriate financial incentives \& penalties (PORTZ, } \\
\text { 2005) }\end{array}$ \\
\hline & \multirow{2}{*}{$\begin{array}{l}\text { Possessing } \\
\text { quick, total } \\
\text { feedback }\end{array}$} & Operation report (formal \& informal) \\
\hline & & Gathering opinions from opinion bo \\
\hline
\end{tabular}

\section{DATA ANALYSIS}

Before conducting any statistical tests, it should be made clear whether the data were gathered from a normal population or not. Having examined the normality of each data, we do the respective hypothesis test concerning the normality or abnormality.

3.1. The statistical test of Kolmogrogh-Smirnogh is presented in the following way:

- The data are normal (the data are not from a normal population): $\mathrm{H}_{0}$

- The data are not normal (the data are from a normal population): $\mathrm{H}_{1}$

If the quantity of the meaningful level is small (smaller than error amount (0.05), hypothesis zero, that is the normality hypothesis, is rejected; otherwise, zero hypothesis is not rejected (HABIBPOUR; SAFARI, 2009). 
INDEPENDENT JOURNAL OF MANAGEMENT \& PRODUCTION (IJM\&P)

http://www.ijmp.jor.br

v. 7, n. 1, January - March 2016

ISSN: 2236-269X

DOI: 10.14807/ijmp.v7i1.372

Table 3: Kolmogragh-Smirnogh one-sample test:

\begin{tabular}{lccc}
\hline \multicolumn{1}{c}{ Research variables } & $\begin{array}{c}\text { policy } \\
\text { environment }\end{array}$ & $\begin{array}{c}\text { Executive } \\
\text { structure }\end{array}$ & policy making \\
\hline Number of samples & 96 & 96 & 96 \\
\hline Average & 4.19 & 4.13 & 4.14 \\
\hline Kolmogragh-Smirnogh Z test & 1.096 & 1.177 & 0.977 \\
\hline Mutual meaningfulness & .181 & .125 & .295 \\
\hline
\end{tabular}

Based on diagram 3 , all meaningfulness ratios are more than 0.05 . So, zero hypothesis $(\mathrm{H})$ which is the normal distribution of the variables, is not rejected. All the 3 variables of the research are of normal distribution.

\subsection{Pearson's correlation coefficients between research variables}

Table 4: Kronbach alpha coefficients and correlation matrix between hidden variables (sample amount $=96$ )

\begin{tabular}{lrrrr}
\hline Research variables & 1 & 2 & 3 & Kronbach alpha \\
\hline 1. Policy environment & 1.00 & & & 0.810 \\
\hline 2. Executive structure & ${ }^{* *} 0.755$ & 1.00 & & 0.857 \\
\hline 3. Policy making & ${ }^{* *} 0.678$ & ${ }^{* *} 0.600$ & 1.00 & 0.851 \\
\hline
\end{tabular}

The meaningfulness level of correlation coefficient of research variables ${ }^{* *} p<0.01 \quad{ }^{*} p<0.05$

Table 4 shows correlation coefficients matrix between hidden variables. The last column shows Kronbach alpha coefficients of variables indicating that all the variables are higher than the accepted minimum amount (0.7) and also representing the stability and validity of measurement tools.

Also, Kronbach alpha coefficient of the whole questionnaire is 0.926 showing the proper stability of the questionnaire. Other numbers are the correlative coefficients between the variables of the research. All of these coefficients are meaningful at 99 percent certainty level marked by $\left({ }^{* *}\right)$ sign.

The largest amount of correlative coefficients is between the two variables of policy environment and executive structure $(0.755)$ showing the powerful, positive, meaningful connection between the two variables. In order to analyze the inner structure of the questionnaire and discovering the constituting elements of each variable, confirmatory factor analysis tools are applied. 
INDEPENDENT JOURNAL OF MANAGEMENT \& PRODUCTION (IJM\&P)

http://www.ijmp.jor.br

v. 7, n. 1, January - March 2016

ISSN: 2236-269X

DOI: 10.14807/ijmp.v7i1.372

The confirmatory factor analysis of the variables of the research are presented in the following way. The abbreviations used in the confirmatory factor analysis are presented in table 5 .

Table 5: Titles related to the variables in confirmatory factor diagram and structural equations

\begin{tabular}{|c|l|l|l|}
\hline \multirow{4}{*}{$\begin{array}{c}\text { Factors arising } \\
\text { from policy } \\
\text { making } \\
\text { Environment }\end{array}$} & \multirow{4}{*}{ Environment } & Events & $\mathrm{E}$ \\
\cline { 3 - 3 } & & Time & $\mathrm{Ti}$ \\
\cline { 3 - 3 } & & Support & $\mathrm{S}$ \\
\cline { 3 - 3 } & Conflict & $\mathrm{C}$ \\
\cline { 3 - 3 } $\begin{array}{c}\text { Factors arising } \\
\text { from structural } \\
\text { organization }\end{array}$ & \multirow{2}{*}{ Structure } & Technology & $\mathrm{Te}$ \\
\hline \multirow{3}{*}{$\begin{array}{c}\text { Factors arising } \\
\text { from policy } \\
\text { making }\end{array}$} & \multirow{4}{*}{ Policy } & Executive & $\mathrm{Ex}$ \\
\cline { 3 - 4 } & & Function & $\mathrm{F}$ \\
\cline { 3 - 4 } & Communication & $\mathrm{Co}$ \\
\hline & & Standard & $\mathrm{St}$ \\
\hline & & Comeory & $\mathrm{Th}$ \\
\hline & & Consensus & $\mathrm{Com}$ \\
\hline
\end{tabular}

Generally, when working with Lizrel software, each of the indexes of the model is not a reason for the fitness or non-fitness of the model by itself, rather these indexes should be interpreted as a whole. Table 6 presents the most important of these indexes and shows that the model has a suitable condition for fit.

Table 6: the fit indexes of conceptual model

\begin{tabular}{|c|r|}
\hline \multicolumn{1}{|l|}{ Index } & Proper limit \\
\hline$\left(\frac{x^{2}}{a f}\right)$ & Less than 3 \\
\hline $\mathrm{GFI}^{1}$ & higher than 0.9 \\
\hline $\mathrm{RMSEA}^{2}$ & less than 0.08 \\
\hline $\mathrm{CFI}^{3}$ & higher than 0.9 \\
\hline $\mathrm{AGFI}^{4}$ & higher than 0.9 \\
\hline
\end{tabular}

\footnotetext{
${ }^{1}$ Goodness of Fit Index (GFI)

2 Root Mean Square Error of Approximation (RMSEA)

${ }^{3}$ Comparative Fit Index (CFI)

${ }^{4}$ Adjusted Goodness of Fit Index (AGFI)
} 
DOI: 10.14807/ijmp.v7i1.372

\subsection{Confirmatory factor analysis and measurement equations related to policy making environment variable}

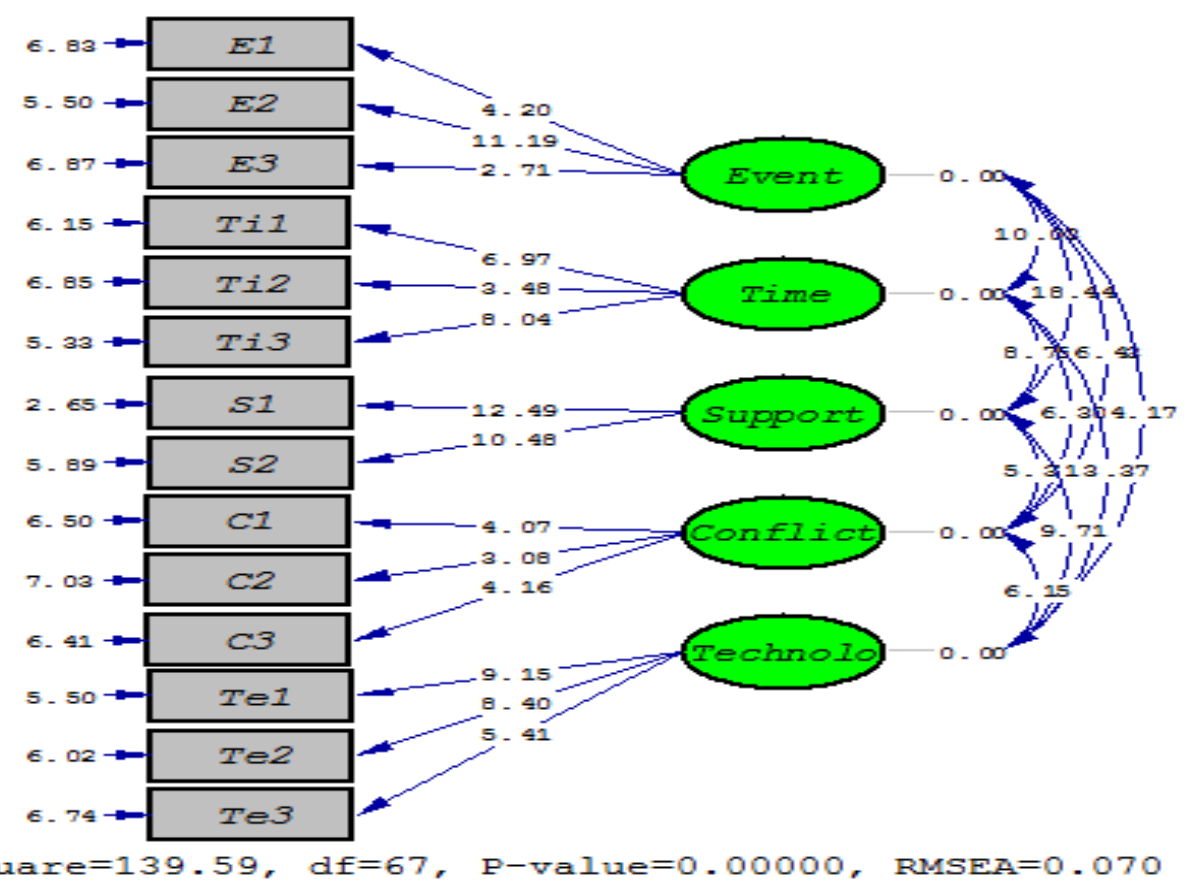

Figure 1: the confirmatory factor analysis model of policy making environment variable (The meaningfulness of coefficients)

The fit index obtained from the confirmatory factor analysis $(K$ on df 2.08 ، GFI=0.95 ، AGFI=0.93 ، $\mathrm{CFI}=0.97$. $\mathrm{NFI}=0.98$ and RMSEA=0.070) shows the proper fit of confirmatory factor analysis. Concerning the meaningfulness of the results of confirmatory factor analysis, all factor loads related to indexes are at 99 percent meaningful certainty level (all factor loads are out of +2 and -2 limit).

Consequently, all the indexes described for the variables are of importance and are considered as indexes. By taking the standardized equations into consideration, it can be understood which index has the major role in the measurement of each dimension. For example, concerning the predictable events variable (Event), the index 2 (E2) (workplace safety \& health) with the load factor 0.95 has the major role in its measurement. Also, index 3 (E3) (natural, organizational, social crisis) with the load factor 0.28 , has the minor role in measuring the predictable events variable.

Confirmatory factor analysis and measurement equations related to the policy making variable. 
DOI: 10.14807/ijmp.v7i1.372

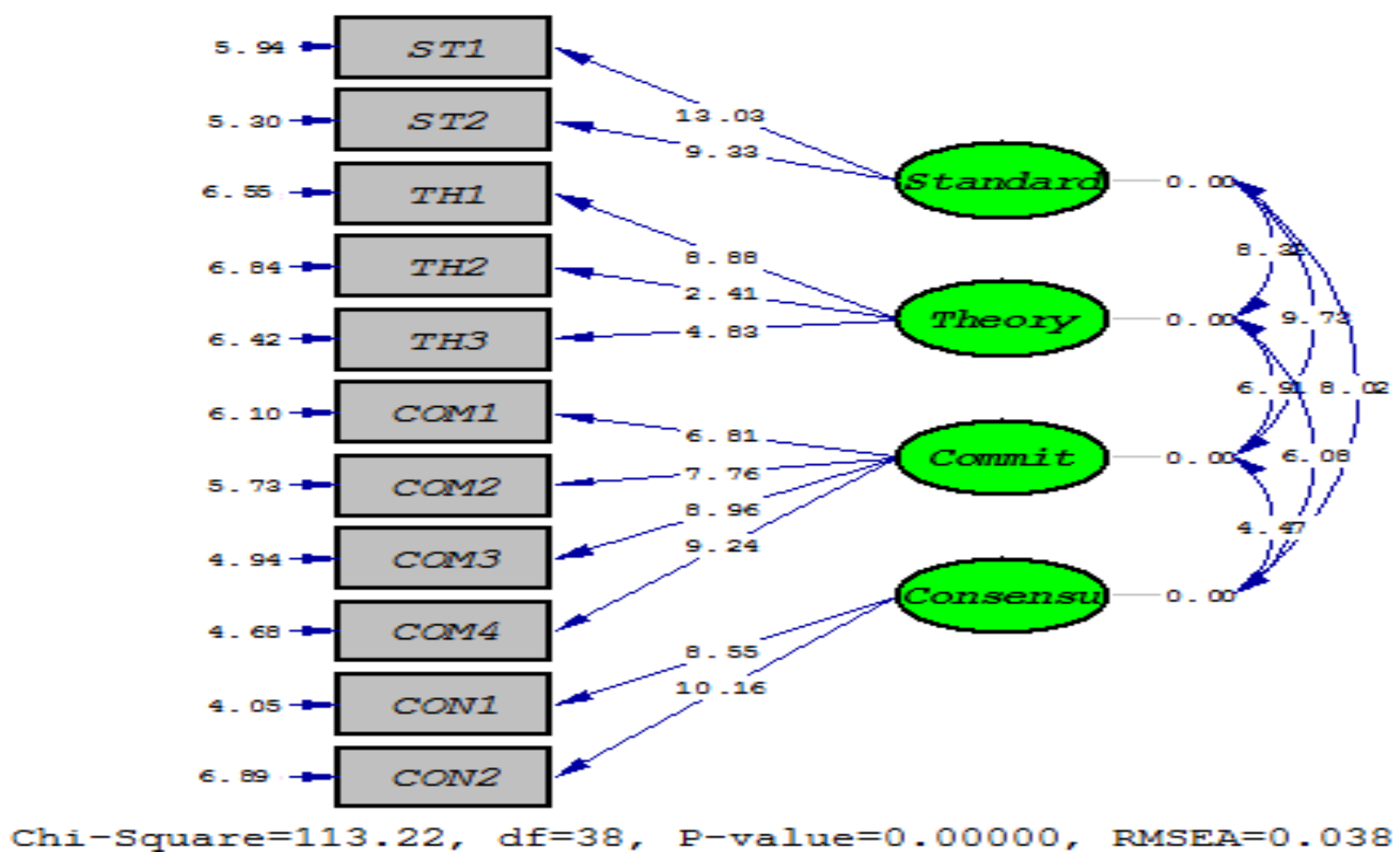

Figure 2: the confirmatory factor analysis model of policy making variable (meaningfulness of coefficients)

The fit index obtained from the confirmatory factor analysis ( $\mathrm{K}$ on df 2.97 , $\mathrm{GFI}=0.94, \mathrm{AGFI}=0.91, \mathrm{CFI}=0.96, \mathrm{NFI}=0.9$, and RMSEA=0.038) shows the proper fit of confirmatory factor analysis. Concerning the meaningfulness of the results of confirmatory factor analysis, all factor loads related with indexes are at 99 percent meaningful certainty level (all factor loads are out of +2 and -2 limit). Consequently, all the indexes described for the variables are of importance and are considered as indexes.

Confirmatory factor analysis and measurement equations related to the organizational structure variable. 
DOI: 10.14807/ijmp.v7i1.372

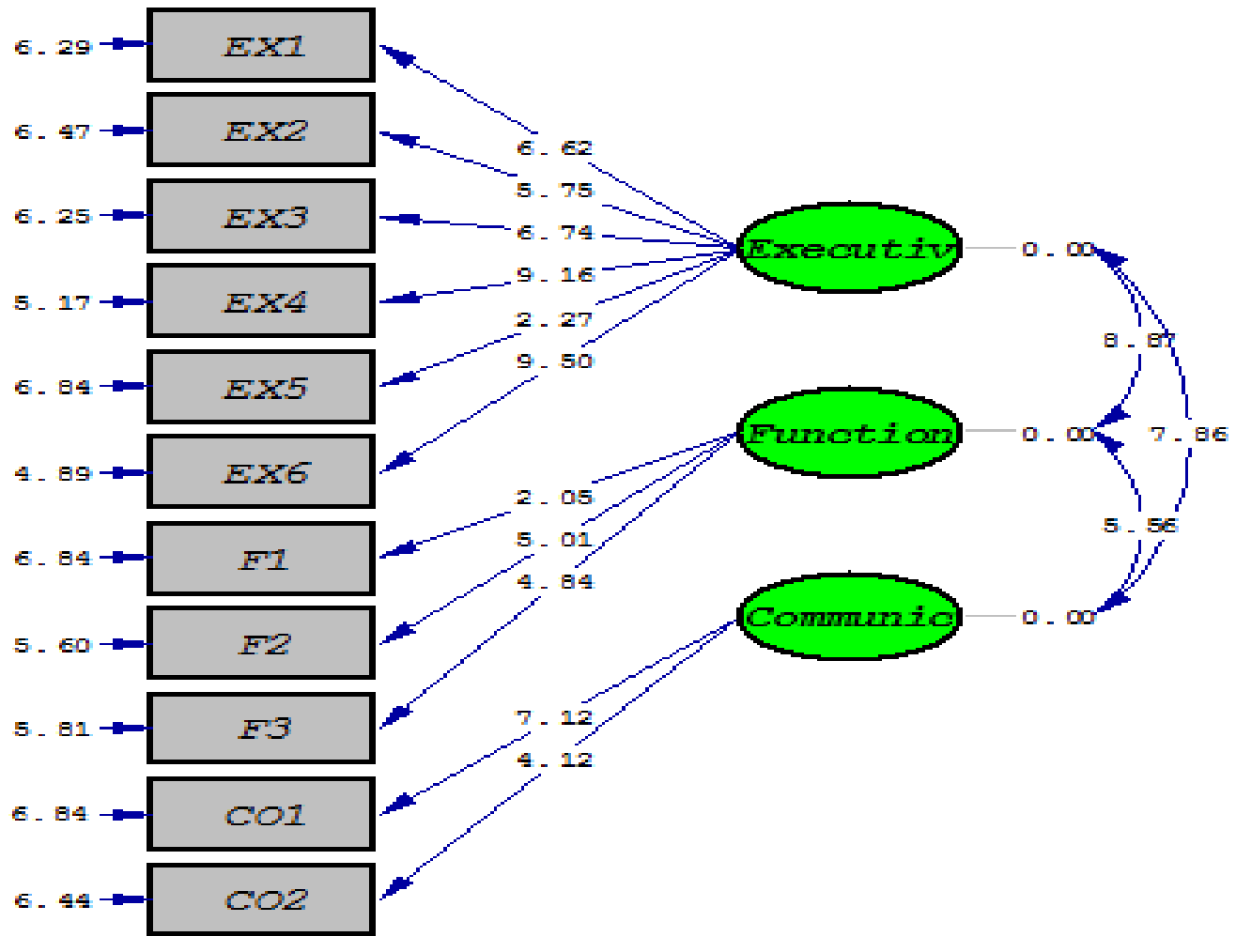

Chi-Square=109.85, df=41, P-value=0.00000, RMSEA=0.057

Figure 3: confirmatory factor analysis model of the organizational structure variable (Meaningfulness of coefficients)

The fit index obtained from the confirmatory factor analysis ( $K$ on df 2.68, $\mathrm{GFI}=0.98, \mathrm{AGFI}=0.95, \mathrm{CFI}=0.97, \mathrm{NFI}=0.96$, and RMSEA=0.057) shows the proper fit of confirmatory factor analysis. Concerning the meaningfulness of the results of confirmatory factor analysis, all factor loads related to indexes are at 99 percent meaningful certainty level (all factor loads are out of +2 and -2 limit). Consequently, all the indexes described for the variables are of importance and are considered as indexes. 
INDEPENDENT JOURNAL OF MANAGEMENT \& PRODUCTION (IJM\&P)

http://www.ijmp.jor.br

v. 7, n. 1, January - March 2016

ISSN: 2236-269X

DOI: 10.14807/ijmp.v7i1.372

\subsection{The second confirmatory factor analysis of the research model}

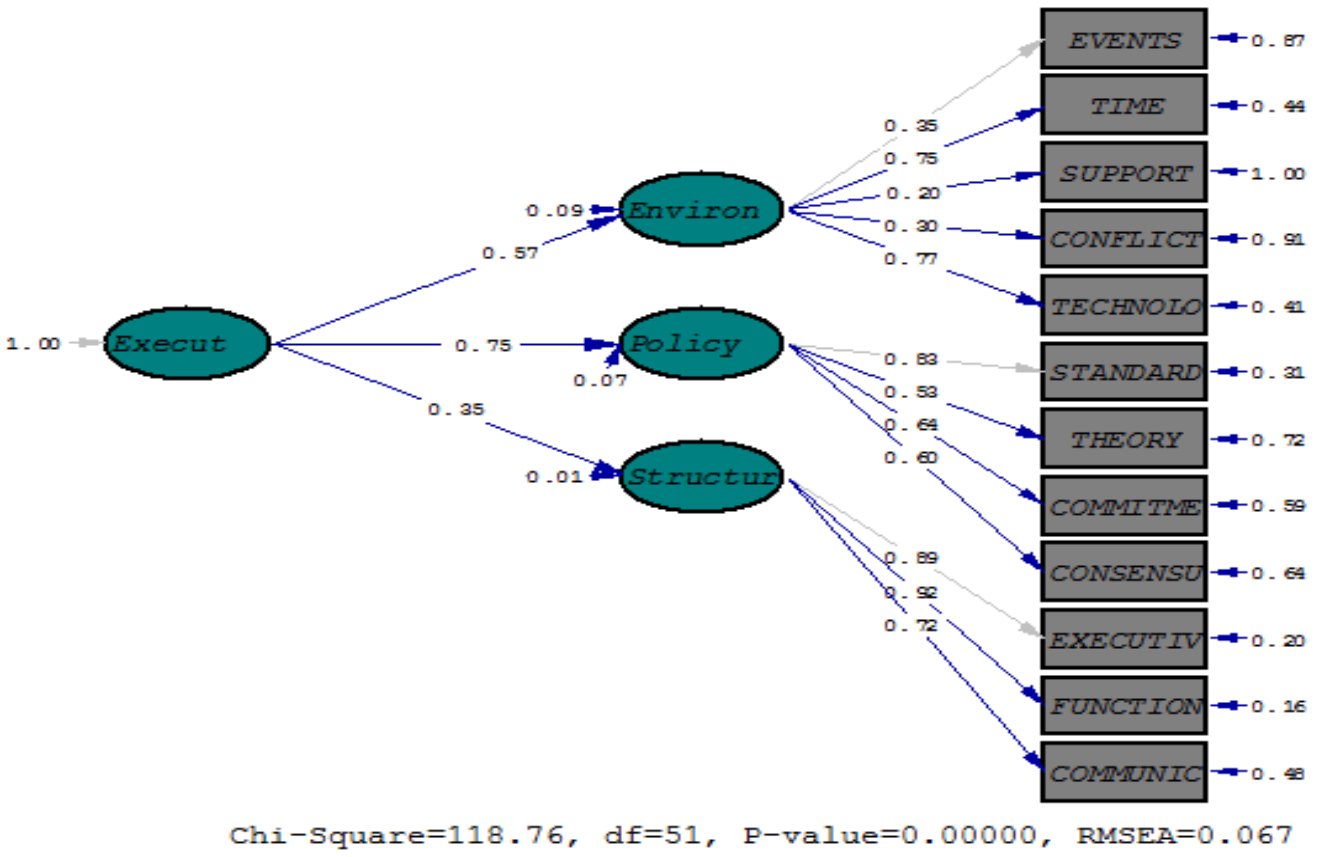

Figure 4: confirmatory factor analysis of the policy making variable (standard)

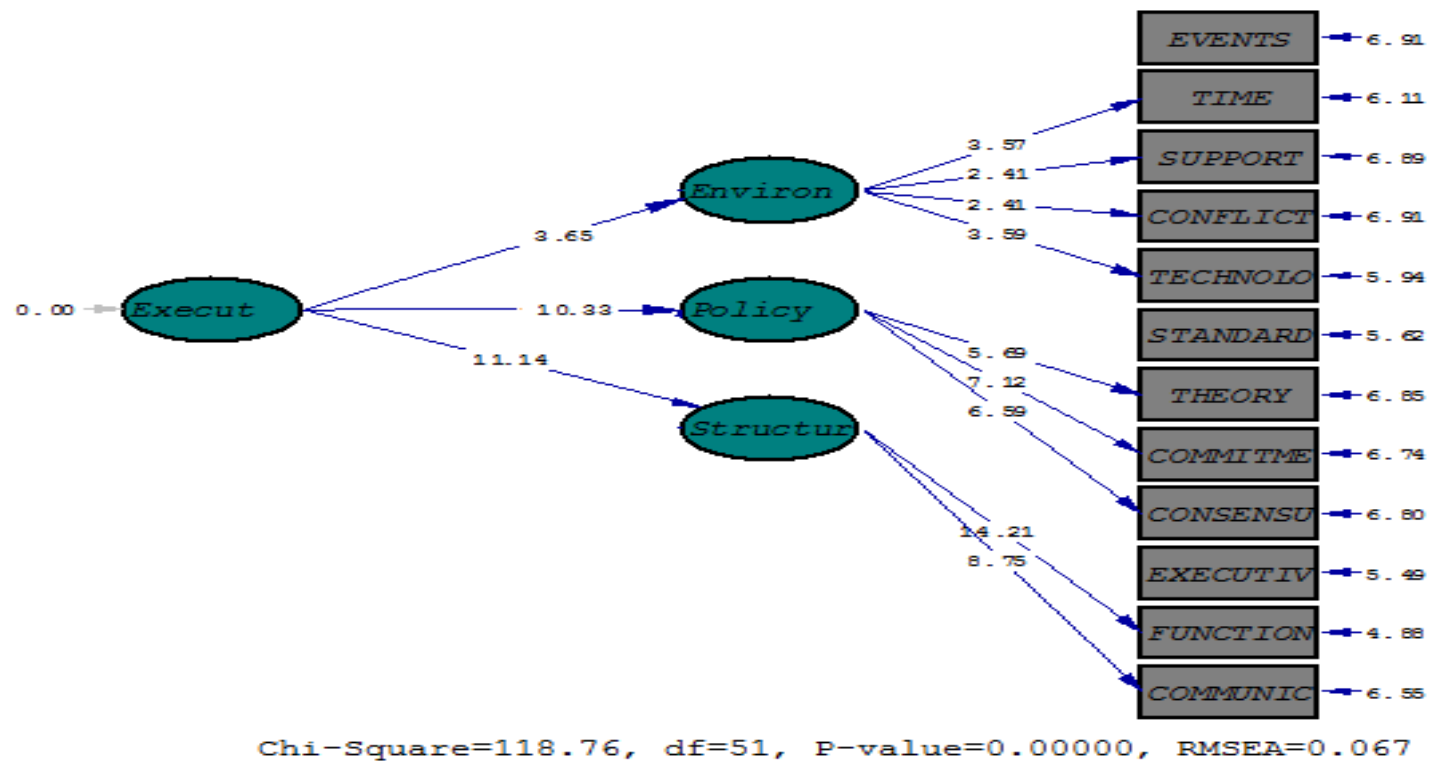

Figure 5: confirmatory factor analysis model of the policy making variable

(meaningfulness of coefficients)

The fit index obtained from the second confirmatory factor analysis ( $\mathrm{K}$ on free dimension 2/33, GFI=0.99, $\mathrm{AGFI}=0.97, \mathrm{CFI}=0.98, \mathrm{NFI}=0.97, \mathrm{RMSEA}=0.067$ ) shows the proper fit of confirmatory factor analysis. Concerning the meaningfulness of the results of confirmatory factor analysis, all factor loads related to indexes are at 99 percent meaningful certainty level (all factor loads are out of +2 and -2 limit). 
DOI: 10.14807/ijmp.v7i1.372

Consequently, all the indexes described for the variables are of importance and are considered as indexes.

In respect of the factor loads (standard coefficients) obtained from the second confirmatory factor analysis (Table 7-10), we are to prioritize the indexes and effective factors of policy making and execution by the Tehran and Qom Agricultural Organization.

Table 7: Prioritization of factors arising from policy making environment and its execution

\begin{tabular}{|c|c|c|}
\hline index(factor) & Factor load & priority(grade) \\
\hline Event & $* * 0.35$ & 3 \\
\hline Time & ${ }^{* *} 0.75$ & 2 \\
\hline Support & $* * 0.20$ & 5 \\
\hline Conflict & ${ }^{* *} 0.30$ & 4 \\
\hline Technology & ${ }^{* *} 0.77$ & 1 \\
\hline
\end{tabular}

Table 8: Prioritization of factors arising from policy making

\begin{tabular}{rrr}
\hline index (factor) & $\begin{array}{r}\text { Factor } \\
\text { load }\end{array}$ & priority(grade) \\
\hline Standard & ${ }^{* *} 0.83$ & 1 \\
Theory & ${ }^{* *} 0.53$ & 4 \\
Commitment & ${ }^{* *} 0.64$ & 2 \\
Consensus & ${ }^{* *} 0.60$ & 3 \\
\hline Meaningfulness level of factor loads ${ }^{* 8 \mathrm{p}}<0.01$ & $* \mathrm{p}<0.05$
\end{tabular}

Table 9: Prioritization of factors arising from organizational structure

\begin{tabular}{rrr}
\hline index (factor) & $\begin{array}{r}\text { Factor } \\
\text { load }\end{array}$ & priority(grade) \\
\hline Executive & ${ }^{* *} 0.89$ & 2 \\
Function & ${ }^{* *} 0.92$ & 1 \\
Communication & ${ }^{* *} 0.72$ & 3
\end{tabular}

Meaningfulness level of factor loads $* \bar{*} \mathrm{p} \approx 0.01 \approx \mathrm{p} \approx 0.05$

Table 10: Prioritization of effective factors in public policy execution

\begin{tabular}{lll}
\hline index (factor) & Factor load & priority (grade) \\
\hline Factors due to policy making environment & ${ }^{* *} 0.57$ & 2 \\
Factors due to policy making & ${ }^{* *} 0.75$ & 1 \\
Factors due to organizational structure & ${ }^{* *} 0.35$ & 3 \\
\hline \multicolumn{1}{c}{ Meaningfulness level of factor loads $* * \mathrm{p}<0.01$} & $\approx \mathrm{p}<0.05$
\end{tabular}

Also, in order to assess the importance of public policy execution indexes of Tehran and Qom Agricultural Organization, the averages of the research variables 
INDEPENDENT JOURNAL OF MANAGEMENT \& PRODUCTION (IJM\&P)

http://www.ijmp.jor.br

v. 7, n. 1, January - March 2016

ISSN: 2236-269X

DOI: 10.14807/ijmp.v7i1.372

between Tehran and Qom respondent groups were compared. The results of the comparison are presented below.

\subsection{Policy making environment variable}

- The averages of variable amounts of policy making environment are not equal in the two groups. $H_{n !} \mu_{1}=\mu_{x}$

- The averages of variable amounts of policy making environment are equal in the two groups. $H_{1}: \mu_{1} \neq \mu_{2}$

- In order to analyze data, a test of comparison was done on the average of the whole grades of policy making environment between the two respondent groups of Tehran (1) and Qom(2)

- The results of these computations presented through SPSS software output are given in table 11.

Table 11: Groups statistics

\begin{tabular}{|l|l|l|l|l|}
\hline Test variable & Sample group & Numbers & Average & Criterion deviation \\
\hline \multirow{2}{*}{$\begin{array}{l}\text { Policy making } \\
\text { environment }\end{array}$} & Tehran & 63 & 4.297 & .614 \\
\cline { 2 - 5 } & Qom & 33 & 3.996 & .499 \\
\hline
\end{tabular}

Table 11 describes the statistics in respect of the two respondent groups in which the number of data and descriptive statistics of policy making environment variable in respect of the two groups are presented individually.

Table 12: the result of the average comparison test of the two populations

\begin{tabular}{|c|c|c|c|c|c|c|c|c|}
\hline & & \multicolumn{2}{|c|}{$\begin{array}{l}\text { Levin test for } \\
\text { equality of ariances }\end{array}$} & \multicolumn{5}{|c|}{$T$ test for the equality of averages } \\
\hline & & \multirow{2}{*}{$\begin{array}{l}\text { F } \\
\text { statistics }\end{array}$} & \multirow{2}{*}{$\begin{array}{l}\text { Meaning } \\
\text { fulness }\end{array}$} & \multirow{2}{*}{$\begin{array}{l}\mathrm{T} \\
\text { statistics }\end{array}$} & \multirow{2}{*}{$\begin{array}{l}\text { meanin } \\
\text { gfulness }\end{array}$} & \multirow{2}{*}{$\begin{array}{l}\text { variance } \\
\quad \text { of } \\
\text { averages }\end{array}$} & \multicolumn{2}{|c|}{$\begin{array}{l}95 \% \text { certainty } \\
\text { distance of } \\
\text { variances }\end{array}$} \\
\hline & & & & & & & $\begin{array}{l}\text { Low } \\
\text { limit }\end{array}$ & $\begin{array}{l}\text { High } \\
\text { limit }\end{array}$ \\
\hline $\begin{array}{l}\text { Policy } \\
\text { making } \\
\text { environ } \\
\text { ment }\end{array}$ & $\begin{array}{l}\text { equality of } \\
\text { variances } \\
\text { Non- } \\
\text { equality of } \\
\text { variances }\end{array}$ & .724 & .397 & 2.427 & .017 & .301 & .055 & .547 \\
\hline
\end{tabular}

Table 12 presents the results of the test and has two parts: the first part deals with the equality test of the variance of the two populations and the second part 
DOI: 10.14807/ijmp.v7i1.372

presents the equality of the average of the two populations in both cases as well as the equality and non-equality of variances.

The statistical hypothesis of the equality of variance test of the two populations (levin) test is as follows:

The variance of the two populations (Tehran \& Qom) are different.

The variance of the two populations (Tehran \& Qom) are the same.

The meaningfulness related to Levin test is equal to 0.397 and higher than $5 \%$ meaningful level. Thus, the equality hypothesis of variances is not rejected. Therefore, we examine the data of the first line for the sake of a conclusion in respect of the average. The average equality test is meaningful in case of the equality of a variance less than $5 \%$. As a result, $\mathrm{H}_{1}$ is rejected and the claim of the average equality of the importance of policy making environment in the two respondent groups, Tehran (1) \& Qom (2), is accepted at 5\% error level.

The results presented in table 12 show that both high and low limits are positive; therefore, the average of the first population (Tehran respondents) is higher than the average of the second population (Qom respondents). As a result, the average of the importance of policy making environment in the Tehran Agricultural Organization is higher than that of the Qom Agricultural Organization.

\subsection{Organizational structure variable}

The averages of variable amounts of organizational structure are not equal in the two groups. $\hbar_{0}: \mu_{1}=\mu_{2}$

The averages of variable amounts of organizational structure are equal in the two groups. $H_{1}: \mu_{1} \neq \mu_{2}$

In order to analyze data, a test of comparison was done on the average of the whole grades of organizational structure between the two respondent groups of Tehran (1) and Qom (2).

The results of these computations presented through SPSS software output are given in table 13 . 
INDEPENDENT JOURNAL OF MANAGEMENT \& PRODUCTION (IJM\&P)

http://www.ijmp.jor.br

v. 7, n. 1, January - March 2016

ISSN: 2236-269X

DOI: 10.14807/ijmp.v7i1.372

Table13: Groups statistics

\begin{tabular}{|l|l|l|l|l|}
\hline Test variable & Sample group & Numbers & Average & Criterion deviation \\
\hline $\begin{array}{l}\text { Organizational } \\
\text { structure }\end{array}$ & Tehran & 63 & 4.243 & .714 \\
\cline { 2 - 5 } & Qom & 33 & 3.926 & .691 \\
\hline
\end{tabular}

Table 13 describes the statistics in respect of the two respondent groups in which the number of data and descriptive statistics of organizational structure variable in respect of the two groups are presented individually.

Table14: the result of the average comparison test of the two populations

\begin{tabular}{|c|c|c|c|c|c|c|c|c|}
\hline & & \multicolumn{2}{|c|}{$\begin{array}{l}\text { Levin test for } \\
\text { equality of ariances }\end{array}$} & \multicolumn{5}{|c|}{$\mathrm{T}$ test for the equality of averages } \\
\hline & & \multirow{2}{*}{$\begin{array}{l}\mathrm{F} \\
\text { statistics }\end{array}$} & \multirow{2}{*}{$\begin{array}{l}\text { Meaning } \\
\text { fulness }\end{array}$} & \multirow{2}{*}{$\begin{array}{l}\mathrm{T} \\
\text { statistics }\end{array}$} & \multirow{2}{*}{$\begin{array}{l}\text { meaning } \\
\text { fulness }\end{array}$} & \multirow{2}{*}{$\begin{array}{l}\text { variance } \\
\text { of } \\
\text { averages }\end{array}$} & \multicolumn{2}{|c|}{$\begin{array}{l}95 \% \text { certainty } \\
\text { distance of } \\
\text { variances }\end{array}$} \\
\hline & & & & & & & $\begin{array}{l}\text { Low } \\
\text { limit }\end{array}$ & $\begin{array}{l}\text { High } \\
\text { limit }\end{array}$ \\
\hline $\begin{array}{l}\text { Organiza } \\
\text { tional } \\
\text { structure }\end{array}$ & $\begin{array}{l}\text { equality of } \\
\text { variances } \\
\text { Non- } \\
\text { equality of } \\
\text { variances }\end{array}$ & .004 & .950 & $\begin{array}{l}2.091 \\
2.112\end{array}$ & $\begin{array}{l}0.039 \\
0.038\end{array}$ & $\begin{array}{l}0.317 \\
0.317\end{array}$ & 0.017 & $\begin{array}{l}0.619 \\
0.617\end{array}$ \\
\hline
\end{tabular}

Table 14 presents the results of the test and consists of two parts: the first part deals with the equality test of the variance of the two populations and the second part presents the equality of the average of the two populations in both cases as well as the equality and non-equality of variances.

The statistical hypothesis of the equality of variance test of the two populations (Levin) test is as follows:

The variance of the two populations (Tehran \& Qom) are different. $H_{0}: \sigma_{1}^{2}=\sigma_{2}^{2}$

The variance of the two populations (Tehran \& Qom) are the same. $H_{1}: \sigma_{1}^{2} \neq \sigma_{2}^{2}$

The meaningfulness related to Levin test is equal to 0.950 and higher than $5 \%$ meaningful level; thus, the equality hypothesis of variance $\left(\mathrm{H}_{1}\right)$ is not rejected. Therefore, we examine the data of the first line for the sake of a conclusion in respect of the average.

The average equality test is meaningful in case of the equality of a variance less than $5 \%(g l g=0.039)$, so, $\mathrm{H}_{1}$ is rejected. Therefore, the claim of the average 
INDEPENDENT JOURNAL OF MANAGEMENT \& PRODUCTION (IJM\&P)

http://www.ijmp.jor.br

v. 7, n. 1, January - March 2016

ISSN: 2236-269X

DOI: 10.14807/ijmp.v7i1.372

equality of the importance of the organizational structure in the two respondent groups, Tehran (1) \& Qom (2) is accepted at 5\% error level.

The results presented in table 14 show that both high and low limits are positive, therefore, the average of the first population (Tehran respondents) is higher than the average of the second population (Qom respondents). Therefore, the average of the importance of organizational structure in the Tehran Agricultural Organization is higher than that of the Qom Agricultural Organization.

\section{7. policy making variable The averages of variable amounts of policy making are not equal in the two groups.}

The averages of variable amounts of policy making are equal in the two groups. $H_{1}: \mu_{1} \neq \mu_{2}$

In order to analyze data, a test of comparison was done on the average of the whole grades of policy making between the two respondent groups of Tehran (1) and Qom (2).

The results of these computations presented through SPSS software output are given in table 15 .

Table15: Group statistics

\begin{tabular}{|l|l|l|l|l|}
\hline Test variable & Sample group & Numbers & Average & Criterion deviation \\
\hline \multirow{3}{*}{ Policy making } & Tehran & 63 & 4.286 & .647 \\
\cline { 2 - 5 } & Qom & 33 & 3.848 & .518 \\
\hline
\end{tabular}

Table 15 describes the statistics in respect of the two respondent groups in which the number of data and descriptive statistics of policy making variable in respect of the two groups are presented individually.

Table16: the result of the average comparison test of the two populations

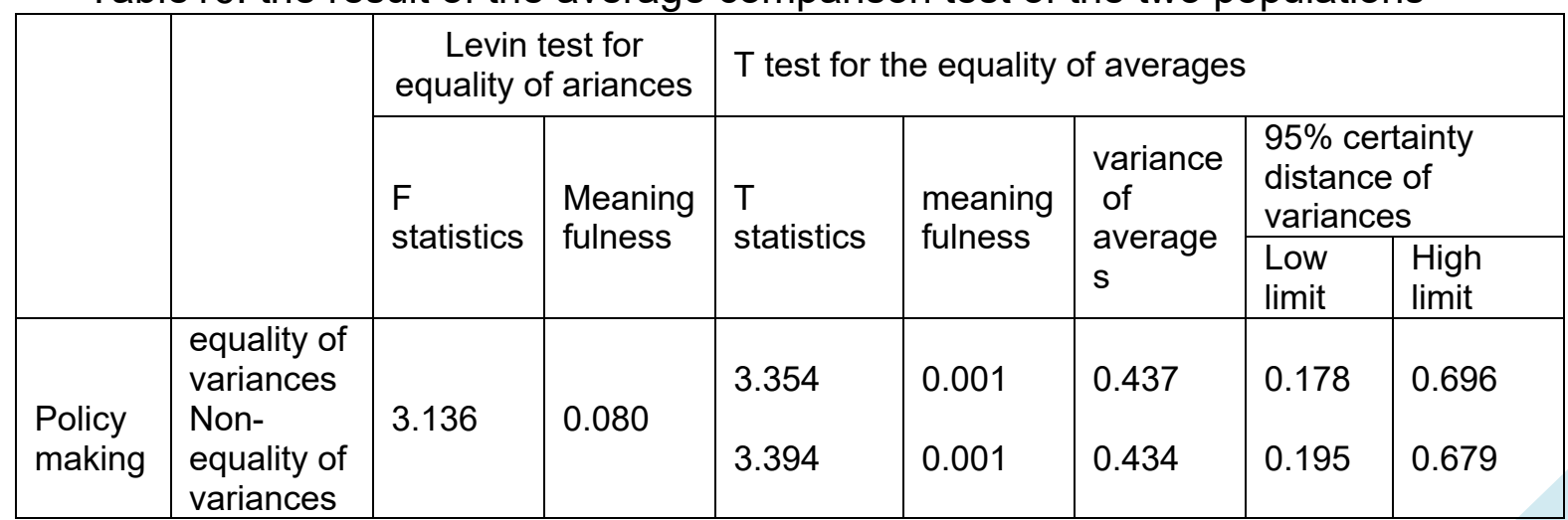


DOI: 10.14807/ijmp.v7i1.372

Table 16 includes the results of the test and consists of two parts: the first part deals with the equality test of the variance of the two populations and the second part presents the equality of the average of the two populations in both cases as well as the equality and non-equality of variances.

The statistical hypothesis related to the equality of variance test of the two populations (Levin test) is as follows:

The variance of the two populations (Tehran \& Qom) are different. $H_{0}: \sigma_{1}^{2}=\sigma_{2}^{2}$

The variance of the two populations (Tehran \& Qom) are the same. $H_{1}: \sigma_{1}^{2} \neq \sigma_{2}^{2}$

The meaningfulness related to the Levin test is equal to 0.950 and higher than $5 \%$ meaningful level. Therefore, the equality hypothesis of variance $(\mathrm{H} 1)$ is not rejected. Subsequently, we examine the data of the first line for the sake of a conclusion in respect of the average.

The average equality test is meaningful in case of the equality of a variance less than $5 \%(2 t g=0.039)$, so, $\mathrm{H}_{1}$ is rejected. Therefore, the claim of the average equality of the importance of policy making in the two respondent groups, Tehran (1) \& Qom (2) is accepted at $5 \%$ error level.

The results presented in table 16 show that both high and low limits are positive, therefore, the average of the first population (Tehran respondents) is higher than the average of the second population (Qom respondents). Therefore, the average of the importance of policy making in the Tehran Agricultural Organization is higher than that of the Qom Agricultural Organization.

\section{CONCLUSION}

For years, agriculture has been a major concern for religious and political authorities. Agriculture is of such importance that it has been selected for a case study to develop indexes of public policy execution. Another reason for this selection is that the need for policy development and implementation is easy to recognize in the agricultural sector. Without a criterion for execution, policy execution would be impossible. 
DOI: 10.14807/ijmp.v7i1.372

So, three classes of factors have been identified in detail for a better execution of policies in the present study and were presented as an operational framework (Table 2). The three classes of effective factors involved in public policy execution are: factors arising from policy making environment, factors arising from policy making, and factors arising from organizational structure.

Each of these factors is divided into evaluative criteria to facilitate execution. According to the results of the analyses, three steps need to be taken for a better execution of agricultural policies: first, the environment should be prepared. Subsequently, policies should be developed in concordance with the execution environment. Finally, executive structure should be designed in the best possible manner.

However, what is new in this study is the comparison of the viewpoints of respondents from the Tehran and Qom Agricultural Organizations. By comparing the average of the research variables between the Tehran \& Qom respondents, it was found that the average importance of the effective factors involved in policy execution in Tehran Agricultural Organization is higher than the average importance of policy making in Qom Agricultural Organization.

In other words, Tehran respondents attached greater importance to the indexes and effective factors of policy execution in the agricultural sector. Another innovation of the research is that the identified indexes can be generalized to all other organizations.

\section{SUGGESTIONS}

The criteria presented in the research, due to the extensiveness of the questions posed, respondents' boredom and reluctance to answer the questions, and also the soft questionnaire approach adopted, need further development, extension and reexamination when applied to other organizations. According to the results, three classes of suggestions, based on identified indexes, can be presented in order for a better development of policy execution.

1. Improving the policy making environment through the application of information technology and electronic tools such as computers, effective exploitation of human and financial resources, predicting and defeating imminent problems, eradicating policy conflicts by adherence to a common 
DOI: 10.14807/ijmp.v7i1.372

value system and its conformity with religious beliefs, and finally the existance of a national concensus and a collective will in favor of the policy execution.

2. Promoting the quality of policies through adapting the policies to the present goals and standards, commitment of politicians to what should be executed, general consensus and agreement on codified policies, exercising rationality in codification of policies and concern for their effectiveness.

3. Lastly, appropriate executive structures should be designed. It would be possible through the clarification of the responsibilities of different sectors involved in policy execution, employing knowledgeable, higly qualified, and committed experts, developing a strong communication network, providing feedback and making continuous assessments.

\section{REFERENCES}

ALVANI, SEIED MEHDI, (2001), Governmental policy decision making \& codification, Tehran, Samt publication, IN PERSIAN

ALVANI, SEIED MEHDI; SHARIFZADE, FATAH (2009) The process of public policy making, Tehran: Allame Tabatabai university publication, IN PERSIAN

AMID ZANJANI, ABBASALI (1995) The principles of Islam's political thought, Tehran, Islamic culture \& thought research center, IN PERSIAN

BOBROW D. B. (2006) Social and cultural factors: constraining and enabling, in: moran M. and Goodin R. E., the oxford handbook of public policy, oxford university press.

COOPER, D. R.; SCHINDLER, S. P. (2003) Business research methods. 8th ed. McGraw Hill

CHUI-HUA LIU A; GWO-HSHIUNG TZENG B. C.; MING-HUEI LEE (2011) Improving tourism policy implementation e The use of hybrid MCDM models, Tourism Management, n. 33, p. 413-426.

EDWARDS, GEORGE C. (1980) Implementation public policy. Washington, D.C: congressional quarterly press.

GHOLIPOUR, RAHMATOLLAH; GHOLAMPOUR AHANGAR, IBRAHIM (2010) public policy making process in Iran, Tehran, The Congress research center, IN PERSIAN

GHOLIPOUR, RAHMATOLLAH (2008) Organizational decision making \& public policy making, Tehran, Samt, IN PERSIAN

HABIBPOUR, KARAM; SAFARI, REZA (2009) A general guide for SPSS application in research (quantitative data analysis, Tehran, Louye, Motefakeran. IN PERSIAN

HUMAN, HEYDAR ALI (2009) Modelling of structural coefficients by Lizerl software, Tehran,Samt. IN PERSIAN 
DOI: 10.14807/ijmp.v7i1.372

KHALID H. M. (2008) Policy implementation models: the case of library and documentation service in Pakistan 1998-2008, New Library World, v. 102, n. 1162

KRUTWAYSHO M. O. (2003) Obstacles to the implementation of tourism policies and regulations in PHUKET, THAILAND, Sheffield Hallam University.

NEJAT, AMIR REZA; YAVARI, ALI REZA (2009) Preparation \&codification of disciplinary operation indexes, two police human resources development journals, sixth year, n. 27,p. 34. IN PERSIAN

SLACK J. D. (2005), limitation policy implementation research, public administration quarterly, $v 29$, n. 1, 2.

SALEHI MILANI, SASAN; MOHAMMADI, MARYAM (2011) Codification of policy making indexes with the purpose of the realization of cultural resistance, civil management, n. 27, p.18 IN PERSIAN

STALEY S. R. (2006) Institutional consideration for sustainable development policy implementation: A US case study, property management, v. 24, n. 3.

TARAS, PAPHNE (2007) public policy: choice, influence, evaluation. Journal labor res, p. 567-571.

TEHRANCHIAN, AMIR MANSOUR (2013) Agriculture's role in Iran economic development, p. 1340-1381, Agriculture Economics Conference

LIANG ZHIMING (2011) Discussion about Policies' Implementation Judgment Rights of Local Government, Procedia, n.13 , p. 2476-2481.

PEYKANI, HADI (2009) A pattern of the process of policy making in education structure of the Islamic Republic of Iran, doctoral Thesis, Tehran Allame University, IN PERSIAN

VARZESHKAR, AHMAD (2008) Index \& index making, defensive management periodicals, fifth year, n. 9, p. 22, IN PERSIAN 